\title{
Resilience of Tourists' Repurchase Intention during the COVID-19 Pandemic: The Shared Accommodation Sector
}

\author{
Yan Wang ${ }^{1}\left(\mathbb{D}\right.$, Kang-Lin Peng ${ }^{2, *}$ (D) and Pearl M. C. Lin $^{3}(\mathbb{D}$ \\ 1 School of Business, Hunan First Normal University, Changsha 410205, China; T17092100131@cityu.mo \\ 2 Faculty of International Tourism and Management, City University of Macau, Macau SAR 999078, China \\ 3 School of Hotel and Tourism Management, Hong Kong Polytechnic University, \\ Hong Kong SAR 999077, China; pearl.lin@polyu.edu.hk \\ * Correspondence: klpeng@cityu.mo; Tel.: +853-85902954
}

Citation: Wang, Y.; Peng, K.-L.; Lin, P.M.C. Resilience of Tourists'

Repurchase Intention during the COVID-19 Pandemic: The Shared Accommodation Sector. Sustainability 2021, 13, 11580. https://doi.org/ $10.3390 /$ su132111580

Academic Editors: Hyung-Min Choi, Hye Jin Sung and Hyeon-Mo Jeon

Received: 29 August 2021

Accepted: 12 October 2021

Published: 20 October 2021

Publisher's Note: MDPI stays neutral with regard to jurisdictional claims in published maps and institutional affiliations.

Copyright: (c) 2021 by the authors. Licensee MDPI, Basel, Switzerland. This article is an open access article distributed under the terms and conditions of the Creative Commons Attribution (CC BY) license (https:/ / creativecommons.org/licenses/by/ $4.0 /)$.

\begin{abstract}
The economy has suffered unprecedentedly during the COVID-19 pandemic, including the shared accommodation sector. This study aims to discover the pandemic consumer behavior model for the recovery of the sector as well as investigate the economic resilience of tourists' behavior to prevent and control the normalized pandemic. Most of the resilience literature discussed the level of economic and industry revitalization. There are relatively few studies on the individual level of tourists' resilience. Therefore, we applied the adjusted theory of planned behavior with pandemic-related intrinsic factors to construct the research model, which is analyzed by the SEM approach. The results show that perceived risk affects tourists' perceived value, trust, and behavioral attitude when repurchasing shared accommodation during the pandemic. The repurchase intention is indirectly affected by the behavioral attitude and perceived value. We concluded that the perceived risk of the pandemic could be resilient with respect to the perceived value, trust, and behavioral attitude for the repurchase intention of the shared accommodation for the sector to recover.
\end{abstract}

Keywords: COVID-19; shared accommodation; perceived risk; perceived value; trust; behavioral attitude; repurchase intention

\section{Introduction}

The COVID-19 pandemic (the pandemic) has triggered significant turbulence world wide. Being affected by the pandemic, cities were locked down, and citizens were forbidden to travel across regions as usual. All sectors of the national economy have been harmed, especially the tourism industry, one of the significant industries suffering the most. According to the Ministry of Culture and Tourism statistics, China had suffered at least a $40 \%$ fall in revenue, reaching nearly 250 million domestic trips and YUAN 280 billion in revenue during the Spring Festival Holiday of 2020 [1]. The tourism industry has been hit hard by the pandemic and resulted in a decline in the tourist economy, including the shared accommodation sector. However, with the effective control of the pandemic and the resilience policy in China, the tourism industry and the shared accommodation sector have regained consumption even in the pandemic era. An urgent issue for the shared accommodation industry is as follows: How to minimize the negative pandemic impacts and further promote the sector development. The sharing economy offers a significant economic contribution, and social innovation originated from Airbnb [2]. Pandemic recovery strategies from the sharing sector can be effective for resilience. The resilience theory was applied in this study, which was developed in the early 1970s to model fluctuations in ecological systems and later applied to linked social-ecological systems. Moreover, it has been explored in various anthropogenic contexts, including applications to tourism [3]. Therefore, in this study, the resilience tourism of the demand side, from the cause of tourists' perceived risk of the pandemic to the effect of the repurchase intention with other influential factors, was explored. 
Compared with traditional hotels, the shared accommodation features diversified suppliers, rich accommodation forms, and a marvelous interaction between the owner and visitor. Moreover, the platform plays a significant role in integrating idle house resources, improving the utilization rate and supply efficiency of idle social resources. Due to the existing pandemic impression, the shared accommodation still faces extraordinary uncertainty. Tourists act more cautiously and rationally than ever before due to the perceived risk of sharing behavior. Will tourists revisit the shared accommodation when traveling during the pandemic? What factors will affect tourists' behavior to revisit the shared accommodation? The perceived risk and concerning factors of revisiting the shared accommodation were studied to recover the sector. The shared accommodation is an emerging sector in the tourism industry, which has played an essential role in economic recovery [4].

The travel accommodation industry should pay attention to consumers' behavior for resilient strategies during the normalization of the pandemic. This case study investigated China's tourist behavior for economic resilience at the prevention and control of the normalized pandemic. In China, the pandemic has been effectively controlled, and the economy is in a state of gradual recovery. People's travel intentions have been increased. However, their travel attitudes are more cautious than in the past due to the normalized pandemic. Therefore, we investigated the repurchase behavior of shared accommodation with the following factors: Perceived risk, trust, perceived value, and behavioral attitude that are significant in consumer behavior and based on the most representative theory that discusses behavioral intentions, which is the theory of planned behavior (TPB) proposed by Ajzen and Fishbein [5]. TPB has become an effective analysis tool for explaining and predicting tourists' intention and behavior. We explore the factors that influence the behavioral attitude and ultimately affect the intention to repurchase the shared accommodation in the post-pandemic era.

This study begins with discussions of the shared accommodation research gaps under the normalized pandemic conditions. Then, it is followed by literature reviews on the tourists' behavioral model in the shared accommodation sector in the Chinese context amid the pandemic. We establish a research model to explore the factors influencing tourists ${ }^{\prime}$ repurchase intention through quantitative approaches. The results present the research model of perceived risk, perceived value, trust, behavioral attitude, and finally, repurchase intention. The conclusions summarize the resilience strategies from the consumer behavior perspective of tourists.

\section{Literature Review}

The COVID-19 pandemic has caused significant impacts on the tourism industry, including the shared accommodation sector, facing uncertain operation difficulties. This study explores resilience approaches by triggering the repurchase intention of shared accommodation from the tourism consumer behavior of perceived risk, perceived value, trust, and behavioral attitude. The shared accommodation sector emerged in the sharing economy, which is different from traditional accommodations, even though there are mix operations of each other. The shared accommodation is a non-standard lodging for landlords or housing operators who rely on the Internet to share idle houses, space, and facilities to obtain economic benefits. Under the pandemic, the perceived risk is the tourists' subjective expectations of losses when purchasing shared accommodations. The perceived value is the overall evaluation of the benefits and costs. Trust refers to the confidence in using the shared accommodation. Behavioral attitudes are the positive or negative evaluations of shared accommodation. Repurchase intentions are defined as the willingness to purchase shared accommodation services again. These five constructs are then discussed in the psychological process of buying the shared accommodation amid the pandemic. 


\subsection{Repurchase Shared Accommodation}

The active subjects of shared accommodation are mainly millennial users such as "post-80s" and "post-90s", and most of them are tourists enjoying family trips and leisure trips [6]. The tourism industry can be recovered by triggering the consumption of these young generations. However, the consumer behavior of tourists is the key to economic recovery during the pandemic. The tourists' repurchase intention of shared accommodation is influenced by intrinsic behavioral factors [7-10], including perceived risk, perceived value, attitude, and trust [11,12]. The theory of planned behavior (TPB) can be adjusted as the theoretical basis with some essential behavioral factors to study the repurchase intention of shared accommodation. According to TPB, the behavioral attitude determines the behavioral intention. The behavioral attitude is an individual's assessment of his behavior [13]. The more positive the attitude, the greater the behavioral intention. From the research, Sweeney and Soutar [14] found that the perception of commodity value is helpful for consumers to form a positive repurchase attitude. Moreover, we found that perceived risk, perceived value, and trust could affect the repurchase intention [15-19].

\subsection{Factors Influencing the Traveling Behavior during the Pandemic}

Travel is considered an essential human activity to connect individuals and the world [20]. However, the perceived risk of the pandemic is a primary concern for traveling. The perceived risk is a consumer's subjective perception of risk and loss [21] that other intrinsic factors can balance. The perceived value, trust, and behavioral attitude can counterfeit the negative effect of perceived risk for the behavioral intention of traveling [22-26]. Zeithaml [27] argued that customers' perceived value is the consumers' subjective perception from a consumer psychology perspective. There are fruitful research findings on the antecedent variables and consequence effects of perceived value. It is found that the perceived risk negatively impacts the perceived value [28,29], then the perceived value impacts the behavioral intention [30,31]. Corbitt et al. [23] indicated that the perceived risk is the antecedent of trust, indirectly affecting the behavioral intention. Trust becomes a significant factor to determine the purchase intention [32]. Trust impacts the consumers' attitudes and behaviors [33] and becomes the main factor affecting the users' willingness to provide or use sharing services [34]. To sum up, for the perceived risk, trust, and perceived value with the TPB construct, the behavioral attitude and repurchase intention can shape a model to analyze the tourists' consumption behavior for the shared accommodation [35].

\subsection{Tourists' Behavioral Model during the Pandemic}

To explore the tourists' behavioral model of shared accommodation during the pandemic, the following literature was explored and demonstrated: The greater the risk perceived by consumers, the smaller the perceived value $[28,29]$. Tourists judge the gains and losses by comparing the conditions of service alternatives according to their perceived risks and pay more attention to the losses. Tourists assess whether the risk of shared accommodation service is high, the mental cost is high, and the return is low, which harms the perceived value.

Hypothesis 1a. Perceived risk negatively affects the perceived value.

Corbitt et al. [23] mentioned that if consumers perceive a product or service with high risk, their trust in it will decrease. In other words, trust is influenced by tourists' perceived risks.

Hypothesis $\mathbf{1 b}$. Perceived risk negatively affects the trust.

The shared accommodation has developed in China for a short time without sound corresponding laws and regulations. Tourists do not have a good sense of shared accommodation products and services. Therefore, their doubts about the shared accommodation 
with perceived risks are inevitable. For example, tourists might worry about the hidden health and safety issues, as well as personal safety. Tourists might confront the cumbersome check-in and check-out procedures, broken facilities, and leakage of personal information. The normalized pandemic has further affected tourists' risk perceptions and brought in tourists' negative attitudes towards the shared accommodation. Corbitt et al. [23] pointed out that the lower the perceived risk, the better their acceptance of online shopping. Zhao and Wang [26] analyzed perceived risk as the main factor influencing shared electric vehicles. The results showed that when consumers perceive a higher risk of the shared electric vehicle, their acceptance will be lower.

Hypothesis 2. Perceived risk negatively affects the behavioral attitude.

Guttentag [36] concluded that the shared accommodation sector could provide unique and authentic accommodation experiences, for example, creative facilities. The housing styles are various, which can meet the diverse needs of travel consumers. The social attribute of shared accommodation is more potent than typical hotels. The host of shared accommodation can be customized to assist guests and establish a closer relationship with guests. Tourists perceived a higher value, which is concerned with these unique attributes and generated positive behaviors and attitudes of shared accommodation [37]. The literature shows that the higher the perceived value, the higher the positive behavioral attitude [38].

Hypothesis 3. Perceived value positively affects the behavioral attitude.

Regarding the relationship between trust and behavioral attitude, the literature revealed that trust could positively impact behavioral attitude [39]. If tourists trust the shared accommodation platform, landlord, and products, they will positively interact with the sharing ecosystem.

Hypothesis 4. Trust positively affects the behavioral attitude.

According to the planned behavior theory of Ajzen and Fishbein [13], the behavioral attitude directly influences the beha vioral intention. The more positive the attitude, the stronger the behavioral intention.

Hypothesis 5. Behavioral attitude positively affects the repurchase intention.

Tourists are less likely to repurchase the product when they perceive higher risks. The higher the perceived risk, the lower the willingness of their repurchase intention [40].

Hypothesis 6. The perceived risk negatively affects the repurchase intention.

Petrick [30] proposed a model for determining the tourists' repurchase intentions. He found that the perceived value influences the repurchase intention. Ranjbarian and Pool [19] indicated that the higher the perceived value, the greater the possibility of the repurchasing service.

Hypothesis 7. Perceived value positively affects the repurchase intention of shared accommodation.

Chiu et al. [15] studied the fact that trust has a positive effect on the online repurchase intention. Moreover, Liang et al. [17] confirmed that the consumers' trust has a positive impact on the repurchase intention.

Hypothesis 8. Tourists' trust positively affects the repurchase intention of shared accommodation. 


\section{Method}

\subsection{Model Completion}

Based on the literature review, the research model is expressed in Figure 1. Moreover, we proposed the hypotheses regarding the mediating effects to complete the research model (1).

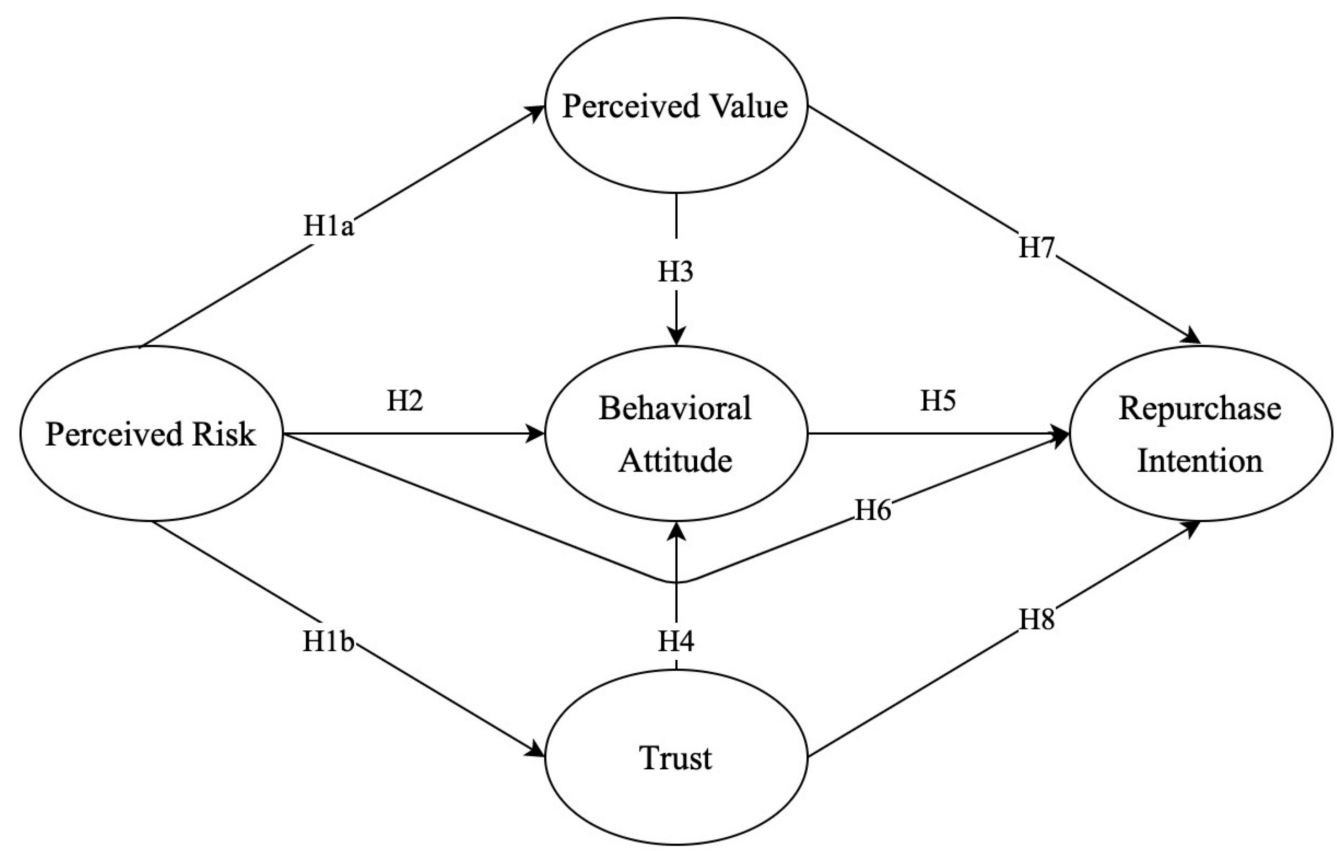

Figure 1. Research model.

Hypothesis 9. Behavioral attitude has a mediating effect between the perceived risk and repurchase intention.

Chang and $\mathrm{Wu}$ [22] found that perceived risk indirectly affects the purchase intention through the behavioral attitude. Based on the study of Airbnb consumer repurchase intention, Mao and Lyu [41] pointed out that perceived risk can only directly and significantly affect the attitude, while it indirectly affects the repurchase intention (2).

Hypothesis 10. Perceived value has a mediating effect between the perceived risk and repurchase intention of shared accommodation.

$\mathrm{Xu}$ et al. [42] pointed out that the mediating effect of perceived value between perceived risk and behavioral intention is significant (3).

Hypothesis 11. Trust has a mediating effect between the perceived risk and the repurchase intention of shared accommodation.

Corbitt et al. [23] showed that perceived risk is the antecedent of trust, which indirectly affects behavioral intention through trust. Mou, Cui and Kurcz [43] proved that consumers' trust in cross-border online shopping could partially mediate between perceived risk and purchase intention.

\subsection{Modeling and Measurement Instrument}

The research model contains five variables, which were measured according to the scales and questionnaire items reviewed in the previous literature. The wording of the questionnaire items was adjusted according to the practical situations of shared accommodation. 
We referred to the measurements of Featherman and Pavlou [44] for the perceived risk. The perceived value scale originated from Zeithaml [27] as well as Gallarza and Saura [45]. For the trust scale, we referred to the scale of Gallarza and Saura [45] and the measurement indicators in the trust of shared vehicle consumers. For the behavioral attitude scale, we mainly drew on the scales of Ajzen and Fishbein [13] and Yoon [46]. The study adopts the scales of Parasuraman et al. [47] and Chiu et al. [48] to measure the repurchase intention. The measurement scales are listed in Table 1.

Table 1. Measurement items and sources of tourists' repurchase intention.

\begin{tabular}{|c|c|}
\hline Number & Measured Variable \\
\hline PR1 & $\begin{array}{l}\text { During the pandemic, sharing accommodation may have hidden health and safety } \\
\text { hazards and cannot guarantee my safety }\end{array}$ \\
\hline PR2 & $\begin{array}{l}\text { During the pandemic, I will feel worried when buying sharing accommodation } \\
\text { products }\end{array}$ \\
\hline PR3 & $\begin{array}{l}\text { During the pandemic, others will think that it is unwise for me to buy sharing } \\
\text { accommodation products }\end{array}$ \\
\hline$P V 1$ & $\begin{array}{l}\text { During the pandemic, I still think it is cost-effective to buy sharing accommodation } \\
\text { products }\end{array}$ \\
\hline$P V 2$ & $\begin{array}{l}\text { Taking all factors into consideration, I think sharing accommodation products are } \\
\text { still worth buying }\end{array}$ \\
\hline$P V 3$ & $\begin{array}{l}\text { Although I perceive certain risks, I feel that the benefits of purchasing sharing } \\
\text { accommodation products outweigh the risks }\end{array}$ \\
\hline TR1 & $\begin{array}{l}\text { I think sharing accommodation platforms and house owners can provide me with } \\
\text { hygienic, safe, as well as reliable products and services }\end{array}$ \\
\hline TR2 & $\begin{array}{l}\text { I believe that sharing accommodation platforms and house owners will fulfill their } \\
\text { promises to consumers }\end{array}$ \\
\hline TR3 & $\begin{array}{l}\text { I believe that sharing accommodation platforms can provide me with a reliable } \\
\text { house owner and protect my privacy }\end{array}$ \\
\hline TR4 & I believe that the house owners deal with sincerity \\
\hline BA1 & $\begin{array}{l}\text { During the pandemic, I think it is necessary to promote sharing accommodation } \\
\text { products }\end{array}$ \\
\hline$B A 2$ & $\begin{array}{l}\text { During the pandemic, I trust sharing accommodation products more than } \\
\text { traditional hotels }\end{array}$ \\
\hline$B A 3$ & During the pandemic, I prefer sharing accommodation products to traditional hotels \\
\hline RI1 & $\begin{array}{l}\text { During the pandemic, I will continue to choose sharing accommodation products } \\
\text { when traveling }\end{array}$ \\
\hline$R I 2$ & $\begin{array}{l}\text { During the pandemic, I prefer to choose sharing accommodation products } \\
\text { when traveling }\end{array}$ \\
\hline RI3 & $\begin{array}{c}\text { During the pandemic, I may always choose shared accommodation products } \\
\text { when traveling }\end{array}$ \\
\hline
\end{tabular}

\subsection{Data Collection and Processing}

During the survey, the questionnaire was delivered by a survey platform of wjx.cn to collect data with a random sampling approach, which ensures the representative of the surveyed groups and softens the influences of a specific region, age, and education level of the survey objects. Data were collected in the fourth quarter of 2020. A total of 540 questionnaires were distributed and 442 valid samples were confirmed after screening, with $81.9 \%$ effective samples. The SPSS26.0 and Mpluse8.3 softwares were applied to analyze the data and test the integrated model's research hypothesis, as shown in Figure 1. The structural equation model (SEM) helps researchers identify the causal relationship between the potential variables by observing the variables [49]. 


\section{Results and Discussion}

\subsection{Results of the Analysis}

The sampling distribution is shown in Table 2 and the representative is well for generalization. The sample profile shows that the young generation is the main customer of the shared accommodation [6]. The Cronbach's $\alpha$ values of the five variables, including perceived risk, perceived value, trust, behavioral attitude, and repurchase intention were $0.874,0.846,0.856,0.899$, and 0.911 , respectively, while the combined reliability (CR) values were $0.876,0.850,0.857,0.905$, and 0.913 , respectively. This indicates the good reliability of the measurement scales. The minimum value of the standardized factor loading was 0.712 , exceeding the factor loading standard of 0.6 , while the minimum value of AVE was 0.596 , exceeding the standard value of 0.5 . In their research, Fornell and Larcker [50] believed that the combined reliability value should be greater than 0.7 , while the AVE value should be greater than 0.5 , which are the ideal values. Therefore, the measurement scale had good convergence validity, as shown in Table 3 . The test results of the discrimination validity of the scale are shown in Table 4 . The square root of the AVE of each latent variable was greater than the correlation coefficient among the latent variables, showing good discrimination.

Table 2. Descriptive statistical results of the sample.

\begin{tabular}{|c|c|c|c|c|}
\hline Items & Categories & Numbers & Percentage\% & $\begin{array}{l}\text { Cumulative } \\
\text { Percentage\% }\end{array}$ \\
\hline \multirow{2}{*}{ Sex } & Male & 171 & 38.69 & 38.69 \\
\hline & Female & 271 & 61.31 & 100.00 \\
\hline \multirow{5}{*}{ Age } & $19-35$ & 335 & 75.80 & 75.80 \\
\hline & $36-45$ & 79 & 17.87 & 93.67 \\
\hline & $46-55$ & 25 & 5.66 & 99.32 \\
\hline & $56-65$ & 1 & 0.23 & 99.55 \\
\hline & 66 or above & 2 & 0.45 & 100.00 \\
\hline \multirow{5}{*}{ Education level } & Junior high school or below & 7 & 1.58 & 1.58 \\
\hline & Senior high school & 19 & 4.30 & 5.88 \\
\hline & College & 68 & 15.38 & 21.27 \\
\hline & Undergraduate & 314 & 71.04 & 92.31 \\
\hline & Postgraduate and above & 34 & 7.69 & 100.00 \\
\hline \multirow{6}{*}{ Roommate type } & Single & 24 & 5.43 & 5.43 \\
\hline & Family relatives & 245 & 55.43 & 60.86 \\
\hline & Friend & 129 & 29.19 & 90.05 \\
\hline & Classmates Colleagues & 40 & 9.05 & 99.10 \\
\hline & neighborhood & 1 & 0.23 & 99.32 \\
\hline & Others & 3 & 0.68 & 100.00 \\
\hline \multirow{3}{*}{ Marital status } & Single & 138 & 31.22 & 31.22 \\
\hline & Married without children & 279 & 63.12 & 94.34 \\
\hline & Married with children & 25 & 5.66 & 100.00 \\
\hline \multirow{6}{*}{$\begin{array}{c}\text { Personal } \\
\text { monthly income } \\
(C N Y)\end{array}$} & 2000 or below & 36 & 8.14 & 8.14 \\
\hline & $2001-4000$ & 53 & 11.99 & 20.14 \\
\hline & $4001-6000$ & 89 & 20.14 & 40.27 \\
\hline & $6001-8000$ & 89 & 20.14 & 60.41 \\
\hline & $8001-10,000$ & 99 & 22.40 & 82.81 \\
\hline & 10,000 or above & 76 & 17.19 & 100.00 \\
\hline
\end{tabular}


Table 3. Results of confirmatory factor analysis.

\begin{tabular}{|c|c|c|c|c|}
\hline Variables & Items & $\begin{array}{l}\text { St Factor } \\
\text { Loading }\end{array}$ & S.E. & $A V E$ \\
\hline \multirow{3}{*}{$P R$} & PR1 & 0.848 & 0.018 & \multirow{3}{*}{0.702} \\
\hline & PR2 & 0.887 & 0.016 & \\
\hline & PR3 & 0.775 & 0.022 & \\
\hline \multirow{3}{*}{$P V$} & PV1 & 0.797 & 0.020 & \multirow{3}{*}{0.654} \\
\hline & PV2 & 0.866 & 0.016 & \\
\hline & PV3 & 0.759 & 0.023 & \\
\hline \multirow{4}{*}{$T R$} & TR1 & 0.815 & 0.020 & \multirow{4}{*}{0.596} \\
\hline & TR2 & 0.797 & 0.021 & \\
\hline & TR3 & 0.761 & 0.023 & \\
\hline & TR4 & 0.712 & 0.027 & \\
\hline \multirow{3}{*}{$B A$} & BA1 & 0.802 & 0.019 & \multirow{3}{*}{0.755} \\
\hline & BA2 & 0.898 & 0.012 & \\
\hline & BA3 & 0.903 & 0.011 & \\
\hline \multirow{3}{*}{$R I$} & RI1 & 0.888 & 0.012 & \multirow{3}{*}{0.777} \\
\hline & RI2 & 0.889 & 0.012 & \\
\hline & RI3 & 0.868 & 0.014 & \\
\hline
\end{tabular}

Table 4. Test results of discrimination validity.

\begin{tabular}{cccccc}
\hline & $\boldsymbol{P R}$ & $\boldsymbol{P V}$ & $\boldsymbol{T R}$ & $\boldsymbol{B A}$ & $\boldsymbol{R} \boldsymbol{I}$ \\
\hline $\boldsymbol{P R}$ & 0.838 & & & & \\
$\boldsymbol{P V}$ & -0.571 & 0.809 & & & \\
$\boldsymbol{T R}$ & -0.585 & 0.735 & 0.772 & & \\
$\boldsymbol{B} \boldsymbol{A}$ & -0.648 & 0.769 & 0.733 & 0.869 & 0.881 \\
$\boldsymbol{R I}$ & -0.646 & 0.788 & 0.710 & 0.850 & \\
\hline
\end{tabular}

The confirmatory factor analysis (CFA) results show the measurement validity with the model fitting index. The results show that $\chi 2 / \mathrm{df}=2.204$, CFI value, and TLI value were 0.978 and 0.972 , respectively, which were greater than the critical value of 0.9. Moreover, the results show that RMSEA and SRMR were 0.054 and 0.025 , which were smaller than the critical value of 0.08 . Therefore, the measurement model could be deemed as having a good model adaptation.

To test the impact of perceived risk on the perceived value, trust, behavioral attitude, and repurchase intention, the results show that $\chi 2 / \mathrm{df}=3.995, \mathrm{CFI}$ value, and TLI value were 0.949 and 0.936 , respectively, while RMSEA and SRMR were 0.082 and 0.075 , indicating that the model had an excellent adaption. The path coefficients between the variables of the model are shown in Figure 1 and Table 5. Seven hypotheses were supported, and two hypotheses were not supported.

The Bootstrap method was applied to test the mediating effects. We examined the mediating effects of perceived value, behavioral attitude, and trust between perceived risk and repurchase intention. Table 6 shows that the $\mathrm{H}_{9}$ and $\mathrm{H}_{10}$ were verified. The perceived value and behavioral attitude had mediation effects between perceived risk and repurchase intention. $\mathrm{H}_{11}$ was insignificant, meaning that trust does not indirectly affect perceived risk and repurchase intention. To sum up, the hypotheses were supported except for $\mathrm{H}_{6}, \mathrm{H}_{8}$, and $\mathrm{H}_{11}$, as shown in Table 7 . Figure 2 also presented research model results: hypotheses supported with solid lines and not supported with dash lines. 
Table 5. Path coefficients of the research model.

\begin{tabular}{ccccc}
\hline Variable Relation & Estimate & S.E. & Est/S.E. & $p$-Value \\
\hline $\boldsymbol{P R} \rightarrow \boldsymbol{P V}$ & -0.723 & 0.032 & -22.695 & $0.000^{*}$ \\
$\boldsymbol{P R} \rightarrow \boldsymbol{T R}$ & -0.746 & 0.030 & -24.779 & $0.000^{*}$ \\
$\boldsymbol{P R} \rightarrow \boldsymbol{B A}$ & -0.199 & 0.059 & -3.394 & $0.001^{*}$ \\
$\boldsymbol{P} \boldsymbol{B} \rightarrow \boldsymbol{B A}$ & 0.476 & 0.058 & 8.135 & $0.000^{*}$ \\
$\boldsymbol{T} \boldsymbol{R} \rightarrow \boldsymbol{B A}$ & 0.333 & 0.062 & 5.345 & $0.000^{*}$ \\
$\boldsymbol{B} \boldsymbol{A} \rightarrow \boldsymbol{R I}$ & 0.624 & 0.069 & 9.035 & $0.000^{*}$ \\
$\boldsymbol{P R} \rightarrow \boldsymbol{R I}$ & -0.045 & 0.050 & -0.906 & 0.365 \\
$\boldsymbol{P} \boldsymbol{V} \rightarrow \boldsymbol{R I}$ & 0.338 & 0.061 & 5.549 & $0.000^{*}$ \\
$\boldsymbol{T} \boldsymbol{R} \rightarrow \boldsymbol{R} \boldsymbol{}$ & -0.004 & 0.056 & -0.069 & 0.945 \\
\hline
\end{tabular}

Table 6. Hypothesis test the mediating effects of the perceived value, behavioral attitude, and trust between perceived risk and repurchase intention.

\begin{tabular}{ccccc}
\hline & Estimate & $\boldsymbol{p}$-Value & \multicolumn{2}{c}{$\mathbf{9 5 \% \text { Confidence Interval }}$} \\
\cline { 4 - 5 } & & & Lower & Upper \\
\hline Indirect effect & -0.735 & 0.000 & -0.848 & -0.626 \\
\hline $\boldsymbol{P R} \rightarrow \boldsymbol{P V} \rightarrow \boldsymbol{R I}$ & -0.245 & $0.000^{*}$ & -0.386 & -0.116 \\
\hline $\boldsymbol{P R} \rightarrow \boldsymbol{B} \boldsymbol{A} \rightarrow \boldsymbol{R I}$ & -0.124 & $0.013^{*}$ & -0.234 & -0.038 \\
\hline $\boldsymbol{P R} \rightarrow \boldsymbol{T R} \rightarrow \boldsymbol{R I}$ & 0.003 & 0.959 & -0.113 & 0.114 \\
\hline $\boldsymbol{P R} \rightarrow \boldsymbol{P V} \rightarrow \boldsymbol{B A} \rightarrow \boldsymbol{R I}$ & -0.215 & $0.000^{*}$ & -0.336 & -0.143 \\
\hline $\boldsymbol{P R} \rightarrow \boldsymbol{T R} \rightarrow \boldsymbol{B A} \rightarrow \boldsymbol{R I}$ & -0.155 & $0.001^{*}$ & -0.270 & -0.082 \\
\hline Direct effect & -0.045 & 0.477 & -0.171 & 0.076 \\
\hline
\end{tabular}

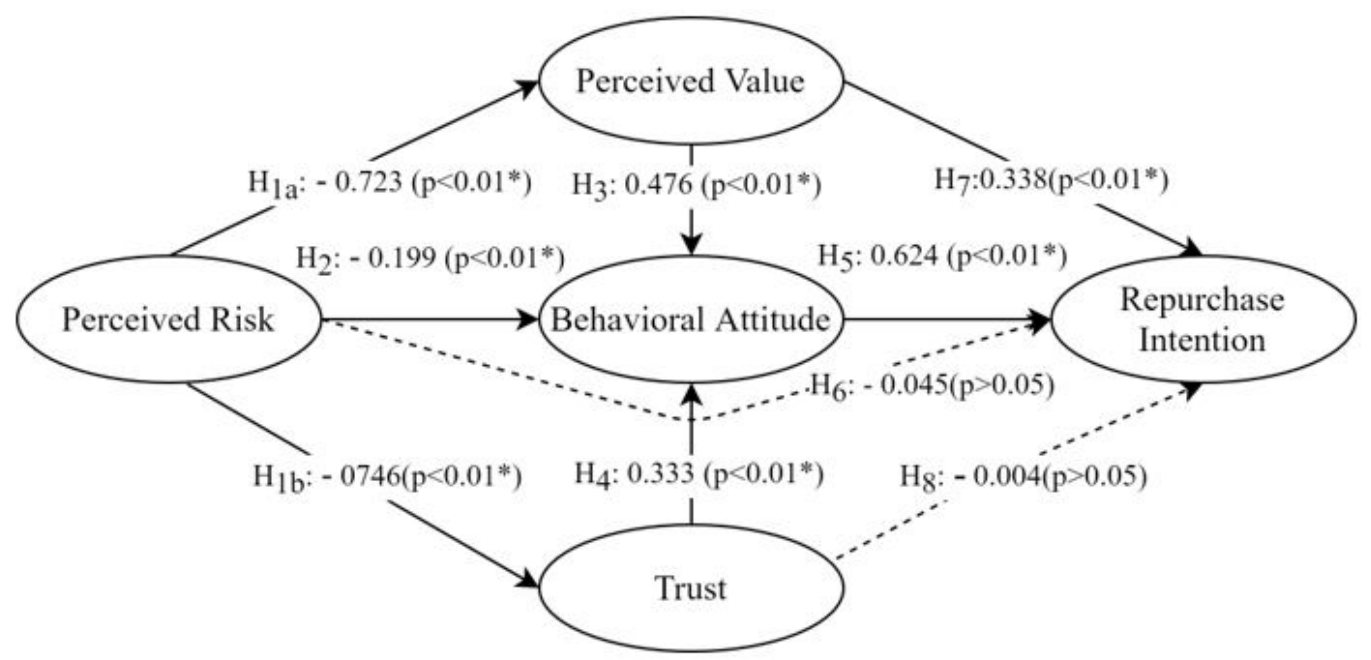

Figure 2. Research model and results. 
Table 7. Summary of results.

\begin{tabular}{|c|c|c|}
\hline No. & Hypothesis & Testing Result \\
\hline$H_{1 a}$ & $\begin{array}{l}\text { Tourism consumers' perceived risk negatively affects } \\
\text { perceived value }\end{array}$ & Supported \\
\hline$H_{1 b}$ & Tourism consumers' perceived risk negatively affects trust & Supported \\
\hline $\mathrm{H}_{2}$ & $\begin{array}{c}\text { Tourism consumers' perceived risk negatively affects } \\
\text { behavioral attitude }\end{array}$ & Supported \\
\hline $\mathrm{H}_{3}$ & $\begin{array}{l}\text { Tourism consumers' perceived value positively affects } \\
\text { behavioral attitude }\end{array}$ & Supported \\
\hline $\mathrm{H}_{4}$ & Tourism consumers' trust positively affects behavioral attitude & Supported \\
\hline$H_{5}$ & $\begin{array}{l}\text { Tourism consumers' attitude positively affects repurchase } \\
\text { intention }\end{array}$ & Supported \\
\hline$H_{6}$ & $\begin{array}{c}\text { Tourism consumers' perceived risk negatively affects } \\
\text { repurchase intention }\end{array}$ & Not Supported \\
\hline$H_{7}$ & $\begin{array}{c}\text { Tourism consumers' perceived value positively affects } \\
\text { repurchase intention }\end{array}$ & Supported \\
\hline$H_{8}$ & Tourism consumers' trust positively affects repurchase intention & Not Supported \\
\hline$H_{9}$ & $\begin{array}{l}\text { Behavioral attitude has a mediation effect between perceived } \\
\text { risk and repurchase intention }\end{array}$ & Supported \\
\hline$H_{10}$ & $\begin{array}{l}\text { Perceived value has a mediation effect between perceived risk } \\
\text { and repurchase intention }\end{array}$ & Supported \\
\hline$H_{11}$ & $\begin{array}{l}\text { Trust has a mediation effect between perceived risk and } \\
\text { repurchase intention }\end{array}$ & Not Supported \\
\hline
\end{tabular}

\subsection{Discussion}

In the pandemic period, the tourists' perceived risk of shared accommodation negatively affects the perceived value. It is consistent with the results that consumers perceive a high risk. They will naturally think that the shared accommodation's cost-effectiveness is low [28]. Moreover, we found that the perceived risk of shared accommodation negatively affects trust. It confirms the claims of Corbitt et al. [23] that when consumers perceive a high risk in shared accommodation, their trust will be negatively influenced.

Moreover, the cause of the perceived risk triggers the negative effect of tourists' behavioral attitude. However, the tourists' perceived value and trust have been proved to affect the behavioral attitude positively. Behavioral attitude is an important variable in the theory of planned behavior and positively affects the repurchase intention. The results comply with the original model hypothesis of planned behavior theory. Furthermore, the behavioral attitude has a mediating effect, which is the fact that the indirect effect of behavioral attitude between perceived risk and repurchase intention is consistent with the literature [22]. The result of perceived risk, with no direct effect on the repurchase intention, has identified the full mediation effect of the behavioral attitude.

The impact of perceived value on the repurchase intention has been widely confirmed [51]. Our study confirms that the higher the perceived value of shared accommodation, the stronger the repurchase intention. Perceived value has played a significant role in the impact of tourists' repurchase intention of shared accommodation during the pandemic. Perceived value directly affects the repurchase intention and has a mediating effect between perceived risk and repurchase intention.

\section{Conclusions}

The primary causality of perceived risk and repurchase intention of shared accommodation products during the pandemic has a practical implication for the economy and the tourism industry recovery. The pandemic has significantly impacted the shared ac- 
commodation sector. Due to the COVID-19 pandemic, China's shared accommodation market decreased by $72.1 \%$, the total number of bookings decreased by $65 \%$, the number of receptions decreased by $63 \%$, and the average room rate decreased by $16 \%$ from January to May 2020 [52].

Although perceived risk does not directly impact tourists' repurchase intention of shared accommodation during the pandemic, the indirect impacts of behavioral attitude and perceived value can construct concerning strategies to promote the repurchase intention. Perceived value plays a crucial role in the repurchase intention by directly affecting the repurchase intention and has an indirect effect between perceived risk and repurchase intention. Therefore, enhancing tourists' perceived value is worth the effort during the pandemic. Behavioral attitude has an important position on the recovery of shared accommodation, as well. The results verify the direct and indirect effects of tourists' behavioral attitude on repurchase intention. Behavioral attitude is intensely subjective and represents people's preferences, which directly affects the repurchase intention. Moreover, it carries the indirect effect between perceived risk and repurchase intention through its mediation effect of lowering the pandemic's perceived risk.

\subsection{Theoretical Contribution}

TPB is a well-known model for consumer behavior. This study adjusted the model with perceived risk, value, and trust to fit tourists' behavior on the shared accommodation for sharing economy theories. When the tourism industry encounters major emergencies such as the COVID-19 pandemic, tourists, as the main body of the tourism industry, play a significant role in the resilient strategies. The research model has contributed to the micro-level of economic resilience. Most of the studies focus on discussing issues from the macro-level of tourism economy and industrial development. Moreover, our study of the consumer behavior of tourists is essential for economic resilience.

\subsection{Managerial Implications}

An integrated model of tourists' repurchase intention of shared accommodation during the pandemic is constructed with perceived risk, perceived value, trust, and behavioral attitude. People are optimistic about the tourism industry's long-term development with a reasonable control of the pandemic. However, the global pandemic situation is still at risk. Tourists are still cautious about the choice of tourism accommodation products, especially the shared accommodation. Their perceived risk requires high standards, such as hygiene, safety, and privacy. The lower perceived risk balanced with perceived value and trust helps the behavioral attitude and repurchase intention. Therefore, sound policies and security systems are the basis for reducing tourists' perceived risk and encouraging the repurchase intention. The pandemic has caused challenges to the tourism industry, operators, and house owners of shared accommodation platforms. To recover the tourism industry, stakeholders must promptly adjust their strategies to ensure the product's security and improve health and safety facilities between buyers and sellers.

Even though there are vaccines, the pandemic is still at risk. The survived institutions in the tourism industry should have strategies to trigger tourists' positive perceived value and behavioral attitude. Small- and medium-sized accommodation operators need to ensure quality and take advantage of sharing economy platforms to seek co-operation with network companies for the maintainenance of tourists' perceived value and behavioral attitude. The tourism industry can use new media for product promotion with the creative cultural and intellectual property for tourists' perceived value. Tourism administrative departments and platform enterprise operators can collaborate to build a trustworthy accommodation environment. Then, the pandemic perceived risk can be balanced by tourists' perceived value, trust, and behavioral attitude for the repurchase intention of shared accommodation. 


\subsection{Limitations and Further Research}

The research only discusses the cause-effect relationship to the behavioral intention without the effect of behavior in the TPB, due to the model simplification. The difficulties of investing tourists' actual travel behaviors amid the pandemic are also challenging to test the effect of TPB behavior. However, most of the previous studies have confirmed that behavioral intentions directly impact behavior as the antecedent cause of tourists' behaviors. As the point of this study, we discuss the impact of the perceived risk of the pandemic. Moreover, the data used in this study are cross-sectional data. It has been a while since the outbreak of the pandemic. Tourists' perceptions of variables such as the perceived risk of shared accommodation products may vary. Therefore, longitudinal data in different periods could be collected to test the results. Furthermore, the measurement scales in this study are referred from the literature with good reliability and validity. However, other factors could be considered, such as customer satisfaction that could influence the repurchase intention during the normalized pandemic. The impact of perceived risk on the repurchase intention may have other potential moderation and mediation variables that need further exploration to improve the research model.

Author Contributions: Conceptualization, Y.W. and K.-L.P.; methodology, Y.W. and K.-L.P.; software, Y.W.; validation, Y.W., K.-L.P. and P.M.C.L.; formal analysis, Y.W.; investigation, Y.W.; resources, K.-L.P.; data curation, Y.W.; writing — original draft preparation, Y.W.; writing—review and editing, K.-L.P. and P.M.C.L.; visualization, K.-L.P. and P.M.C.L.; supervision, K.-L.P.; project administration, Y.W.; funding acquisition, Y.W. All authors have read and agreed to the published version of the manuscript.

Funding: This research received no external funding.

Institutional Review Board Statement: Not applicable.

Informed Consent Statement: Not applicable.

Data Availability Statement: The datasets generated during and analysed during the current study are available from the corresponding author on reasonable request.

Acknowledgments: We take this opportunity to express our profound gratitude and deep regards to Timothy Lee for his encouragement of writing this paper.

Conflicts of Interest: The authors declare no conflict of interest.

\section{References}

1. Mohsin, A.K.M.; Hongzhen, L.; Hossain, S.F.A. Impact of COVID-19 Pandemic on Consumer Economy: Countermeasures Analysis. SAGE Open 2021, 11, 21582440211008875. [CrossRef]

2. Zervas, G.; Proserpio, D.; Byers, J.W. The Rise of the Sharing Economy: Estimating the Impact of Airbnb on the Hotel Industry. J. Mark. Res. 2017, 54, 687-705. [CrossRef]

3. Cochrane, J. The Sphere of Tourism Resilience. Tour. Recreat. Res. 2015, 35, 173-185. [CrossRef]

4. Hossain, M. The effect of the COVID-19 on sharing economy activities. J. Clean. Prod. 2021, 280, 124782. [CrossRef]

5. Ajzen, I.; Fishbein, M. Understanding Attitudes and Predicting Social Behavior; Prentice-Hall: Englewood Cliffs, NJ, USA, 1980.

6. Dychtwald, Z. Young China: How the Restless Generation Will Change Their Country and the World; St. Martin's Press: New York, NY, USA, 2018.

7. Bae, S.J.; Lee, H.; Suh, E.-K.; Suh, K.-S. Shared experience in pretrip and experience sharing in posttrip: A survey of Airbnb users. Inf. Manag. 2017, 54, 714-727. [CrossRef]

8. Ert, E.; Fleischer, A.; Magen, N. Trust and reputation in the sharing economy: The role of personal photos in Airbnb. Tour. Manag. 2016, 55, 62-73. [CrossRef]

9. Guttentag, D.; Smith, S.; Potwarka, L.; Havitz, M. Why Tourists Choose Airbnb: A Motivation-Based Segmentation Study. J. Travel Res. 2017, 57, 342-359. [CrossRef]

10. Tussyadiah, I.P.; Pesonen, J. Impacts of Peer-to-Peer Accommodation Use on Travel Patterns. J. Travel Res. 2016, 55, 1022-1040. [CrossRef]

11. Brochado, A.; Troilo, M.; Shah, A. Airbnb customer experience: Evidence of convergence across three countries. Ann. Tour. Res. 2017, 63, 210-212. [CrossRef]

12. Cheng, M.; Jin, X. What do Airbnb users care about? An analysis of online review comments. Int. J. Hosp. Manag. 2019, 76, 58-70. [CrossRef] 
13. Ajzen, I.; Fishbein, M. A Bayesian analysis of attribution processes. Psychol. Bull. 1975, 82, 261-277. [CrossRef]

14. Sweeney, J.C.; Soutar, G. Consumer perceived value: The development of a multiple item scale. J. Retail. 2001, 77, 203-220. [CrossRef]

15. Chiu, C.-M.; Hsu, M.-H.; Lai, H.; Chang, C.-M. Re-examining the influence of trust on online repeat purchase intention: The moderating role of habit and its antecedents. Decis. Support. Syst. 2012, 53, 835-845. [CrossRef]

16. Davidow, M. Have You Heard the Word? The Effect of Word of Mouth on Perceived Justice, Kepuasan and Repurchase Intentions Following Komplain Handling. J. Complain. Behav. 2003, 16, 190-204.

17. Liang, L.J.; Choi, H.C.; Joppe, M. Understanding repurchase intention of Airbnb consumers: Perceived authenticity, electronic word-of-mouth, and price sensitivity. J. Travel Tour. Mark. 2018, 35, 73-89. [CrossRef]

18. Mittal, V.; Kamakura, W.A. Satisfaction, Repurchase Intent, and Repurchase Behavior: Investigating the Moderating Effect of Customer Characteristics. J. Mark. Res. 2001, 38, 131-142. [CrossRef]

19. Ranjbarian, B.; Pool, J.K. The Impact of Perceived Quality and Value on Tourists' Satisfaction and Intention to Revisit Nowshahr City of Iran. J. Qual. Assur. Hosp. Tour. 2015, 16, 103-117. [CrossRef]

20. Cheung, C.; Takashima, M.; Choi, H.; Yang, H.; Tung, V. The impact of COVID-19 pandemic on the psychological needs of tourists: Implications for the travel and tourism industry. J. Travel Tour. Mark. 2021, 38, 155-166. [CrossRef]

21. Bauer, R.A. Consumer Behavior as Risk Taking. W: Dynamic Marketing for a Changing World. In Proceedings of the 43rd Conference of the American Marketing Association, Chicago, IL, USA, 15-17 June 1960.

22. Chang, M.-L.; Wu, W.-Y. Revisiting Perceived Risk in the Context of Online Shopping: An Alternative Perspective of DecisionMaking Styles. Psychol. Mark. 2012, 29, 378-400. [CrossRef]

23. Corbitt, B.J.; Thanasankit, T.; Yi, H. Trust and e-commerce: A study of consumer perceptions. Electron. Commer. Res. Appl. 2003, 2, 203-215. [CrossRef]

24. Wei, C. The influence of Consumers' Purchase intention on Smart Wearable Device: A study of Consumers in East China. Int. J. Sci. Bus. 2021, 5, 46-72. [CrossRef]

25. Martins, C.; Oliveira, T.; Popovič, A. Understanding the Internet banking adoption: A unified theory of acceptance and use of technology and perceived risk application. Int. J. Inf. Manag. 2014, 34, 1-13. [CrossRef]

26. Zhao, M.; Wang, S.Y. Investigating the intention for Electric Vehicle Sharing. J. Dalian Univ. Technol. (Soc. Sci.) 2018, 39, 36-42. [CrossRef]

27. Zeithaml, V.A. Consumer Perceptions of Price, Quality, and Value: A Means-End Model and Synthesis of Evidence. J. Mark. 1988, 52, 2-22. [CrossRef]

28. Klemz, B.R.; Boshoff, C. Environmental and emotional influences on willingness-to-buy in small and large retailers. Eur. J. Mark. 2001, 35, 70-91. [CrossRef]

29. Wang, C.; Wang, X.C. Research on the Factors Impacting on Chinese Consumers'Willingness to Buy Based on Value Theory in E-shopping. J. Appl. Stat. Manag. 2011, 30, 127-135. [CrossRef]

30. Petrick, J.F. Development of a Multi-Dimensional Scale for Measuring the Perceived Value of a Service. J. Leis. Res. 2002, 34, 119-134. [CrossRef]

31. Ulaga, W. Customer Value in Business Markets. Ind. Mark. Manag. 2001, 30, 315-319. [CrossRef]

32. Ellen, G.; Johnson, M.S. The Different Roles of Satisfaction, Trust, and Commitment in Customer Relationships. J. Market. 1999, 63, 70-87. [CrossRef]

33. Fygenson, P. Understanding and Predicting Electronic Commerce Adoption: An Extension of the Theory of Planned Behavior. MIS Q. 2006, 30, 115. [CrossRef]

34. Hamari, J.; Sjöklint, M.; Ukkonen, A. The sharing economy: Why people participate in collaborative consumption. J. Assoc. Inf. Sci. Technol. 2016, 67, 2047-2059. [CrossRef]

35. Hawlitschek, F.; Teubner, T.; Gimpel, H. Understanding the Sharing Economy-Drivers and Impediments for Participation in Peer-to-Peer Rental. In Proceedings of the 2016 49th Hawaii International Conference on System Sciences (HICSS), Koloa, HI, USA, 5-8 January 2016; pp. 4782-4791.

36. Guttentag, D. Airbnb: Disruptive innovation and the rise of an informal tourism accommodation sector. Curr. Issues Tour. 2015, 18, 1192-1217. [CrossRef]

37. Hill, D. How much is your spare room worth? IEEE Spectr. 2015, 52, 32-58. [CrossRef]

38. Ruiz-Molina, M.E.; Gil-Saura, I. Perceived value, customer attitude and loyalty in retailing. J. Retail. Leis. Prop. 2008, 7, 305-314. [CrossRef]

39. Wu, I.-L.; Chen, J.-L. An extension of Trust and TAM model with TPB in the initial adoption of on-line tax: An empirical study. Int. J. Hum.-Comput. Stud. 2005, 62, 784-808. [CrossRef]

40. Garretson, J.A.; Clow, K.E. The influence of coupon face value on service quality expectations, risk perceptions and purchase intentions in the dental industry. J. Serv. Mark. 1999, 13, 59-72. [CrossRef]

41. Mao, Z.; Lyu, J. Why travelers use Airbnb again? Int. J. Contemp. Hosp. Manag. 2017, 29, 2464-2482. [CrossRef]

42. Xu, F.; Li, S.S.; Niu, W.X.; Lin, X.J. How to Manage Tourist Destination Risk Effectively?-Evidence from Southern Xinjiang. Nankai Bus. Rev. 2019, 22, 66-75. [CrossRef]

43. Mou, J.; Cui, Y.; Kurcz, K. Trust, risk and alternative website quality in B-buyer acceptance of cross-border E-commerce. J. Glob. Inf. Manag. (JGIM) 2020, 28, 167-188. [CrossRef] 
44. Featherman, M.S.; Pavlou, P.A. Predicting e-services adoption: A perceived risk facets perspective. Int. J. Hum. Comput. Stud. 2003, 59, 451-474. [CrossRef]

45. Gallarza, M.G.; Saura, I.G. Value dimensions, perceived value, satisfaction and loyalty: An investigation of university students' travel behaviour. Tour. Manag. 2006, 27, 437-452. [CrossRef]

46. Yoon, C. Theory of Planned Behavior and Ethics Theory in Digital Piracy: An Integrated Model. J. Bus. Ethic 2010, $100,405-417$. [CrossRef]

47. Parasuraman, A.; Zeithaml, V.A.; Malhotra, A. ES-QUAL: A multiple-item scale for assessing electronic service quality. J. Serv. Res. 2005, 7, 213-233. [CrossRef]

48. Chiu, C.-M.; Fang, Y.-H.; Cheng, H.-L.; Yen, C. On online repurchase intentions: Antecedents and the moderating role of switching cost. Hum. Syst. Manag. 2013, 32, 283-296. [CrossRef]

49. Reisinger, Y.; Turner, L. Structural equation modeling with Lisrel: Application in tourism. Tour. Manag. 1999, 20, 71-88. [CrossRef]

50. Fornell, C.; Larcker, D.F. Evaluating Structural Equation Models with Unobservable Variables and Measurement Error. J. Mark. Res. 1981, 24, 337-346. [CrossRef]

51. Cronin, J.J.; Taylor, S.A. Measuring Service Quality-A Reexamination And Extension. J. Mark. 1992, 56, 55-68. [CrossRef]

52. Zhang, M.; Geng, R.; Huang, Y.; Ren, S. Terminator or accelerator? Lessons from the peer-to-peer accommodation hosts in China in responses to COVID-19. Int. J. Hosp. Manag. 2021, 92, 102760. [CrossRef] 